\title{
Vietnamese Regional Planning: Problems in Implementation and International Experiences
}

\author{
Nguyen Thanh Nguyen ${ }^{1}$ \\ ${ }^{1}$ People's Committee of Long An Province, Economic Department, Tan An City, Long An, Vietnam \\ Correspondence: Nguyen Thanh Nguyen, People's Committee of Long An Province, Economic Department, 61 \\ Nguyen Hue street, Tan An City, Long An, Vietnam. Tel: 84-72-382-1694. E-mail: thanhnguyen@longan.gov.vn; \\ thanhnguyenla57@yahoo.com
}

Received: June 14, 2015 Accepted: June 22, 2015 Online Published: September 27, 2015

doi:10.5539/jsd.v8n8p86 URL: http://dx.doi.org/10.5539/jsd.v8n8p86

\begin{abstract}
Vietnam is one of Southeast Asian countries which is realizing its regional plans with success and also failure. This paper aims to present Vietnamese regional planning and the difficulties it faces when implemented. The problem with the organization of territorial management is also explored. This paper argues that this is due to the lack of regional leadership, which could implement the application of planning effectively. The paper also presents other mistakes formed through planned urbanization, infrastructure, and regional economy. In addition, it highlights the responsibilities that divisions of Vietnamese regional governments have in planning. In order to overcome complications in regional planning, the article proposes that the Socialist Republic of Vietnam, and other developing countries, learn from international experiences and resolutions.
\end{abstract}

Keywords: regional planning, problems, implementation, collaboration, Socialist Republic of Vietnam

\section{Introduction}

The Socialist Republic of Vietnam is a developing country that is experiencing industrialization and urbanization. Since the end of French Colonial rule in 1945, and reunification in 1975, the Vietnamese have maintained an old system of governance and a territorial division of state (Constitution of Vietnam, 2013). In recent years, under the pressures of balanced development among Vietnamese areas, the government has established key economic areas with their own plans. The goal is to build strong urbanized economic regions, which trigger the impetus for a snappy development of the Socialist Republic of Vietnam. After nearly ten years, these regional plans seem to have achieved few results due to poor governance and mistakes created in regional planning. This paper will analyze the problems and faults made in Vietnamese regional planning.

\subsection{Territorial Division and the Structure of Government}

From 1946 to 2013, the territorial division of the Vietnam, as its institution, has seen no alteration. The state divides into provinces and central municipalities. Provinces divide into districts, county towns and provincial cities. As well, central municipalities divide into urban districts and districts; districts divide into communes and towns, and urban districts into wards... (As shown Figure 1). 


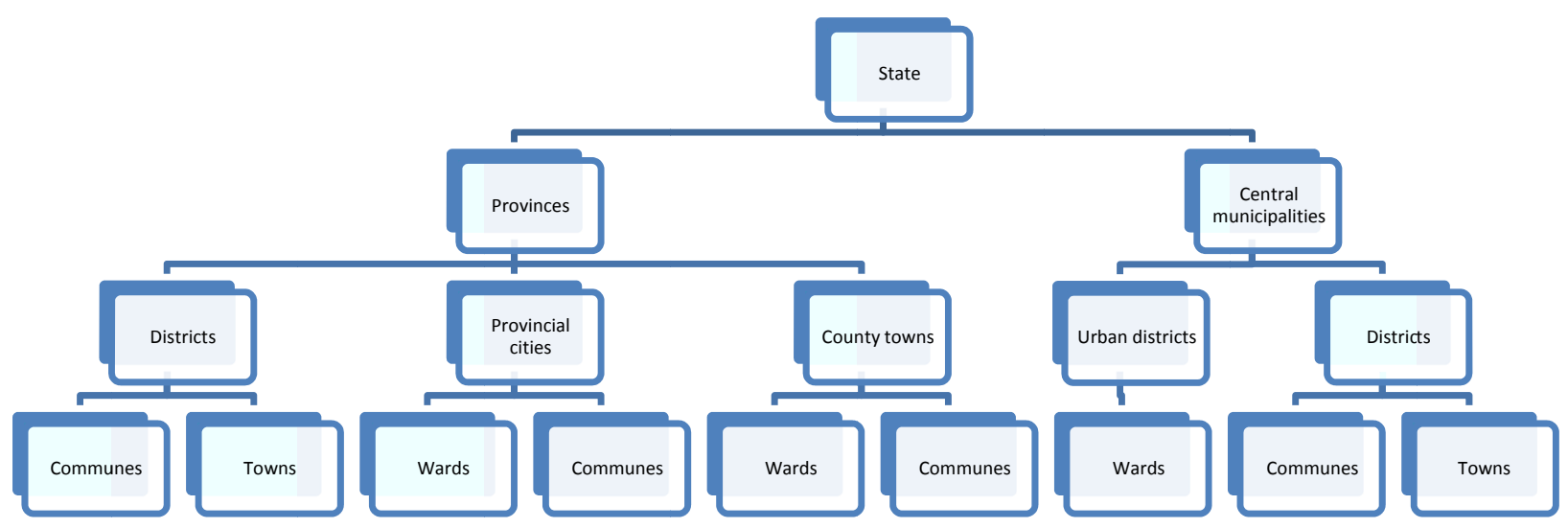

Figure 1. Territorial division

Source: 2013 Constitution

With this territorial division, there are corresponding legislative and executive bodies. The legislative body is established in four levels. At the top of the legislative body is the National Assembly (one chamber), which grasps the highest power and has the authority to issue laws, decide on key issues and supervise other branches. In the level of provinces (and central municipalities), districts (and equivalent), and communes (and equivalent), there are People's Councils that have the power to introduce local regulations, pass annual budgets and also monitor local authorities (As shown Figure 2).

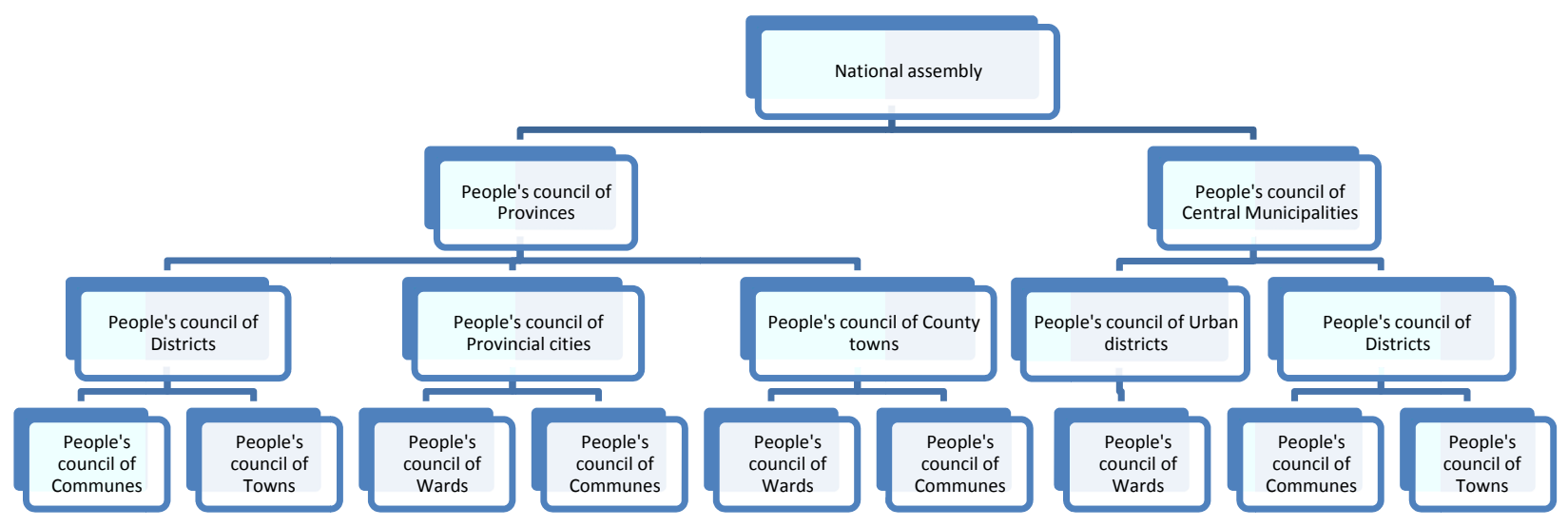

Figure 2. The legislative body

Source: 2013 Constitution

The executive body consists of a central government with a Prime Minister, who manages it. As well, ministries help the Prime Minister. In the level of three local governments, People's Committees grasp the executive power in their respective territories (As shown Figure 3). 


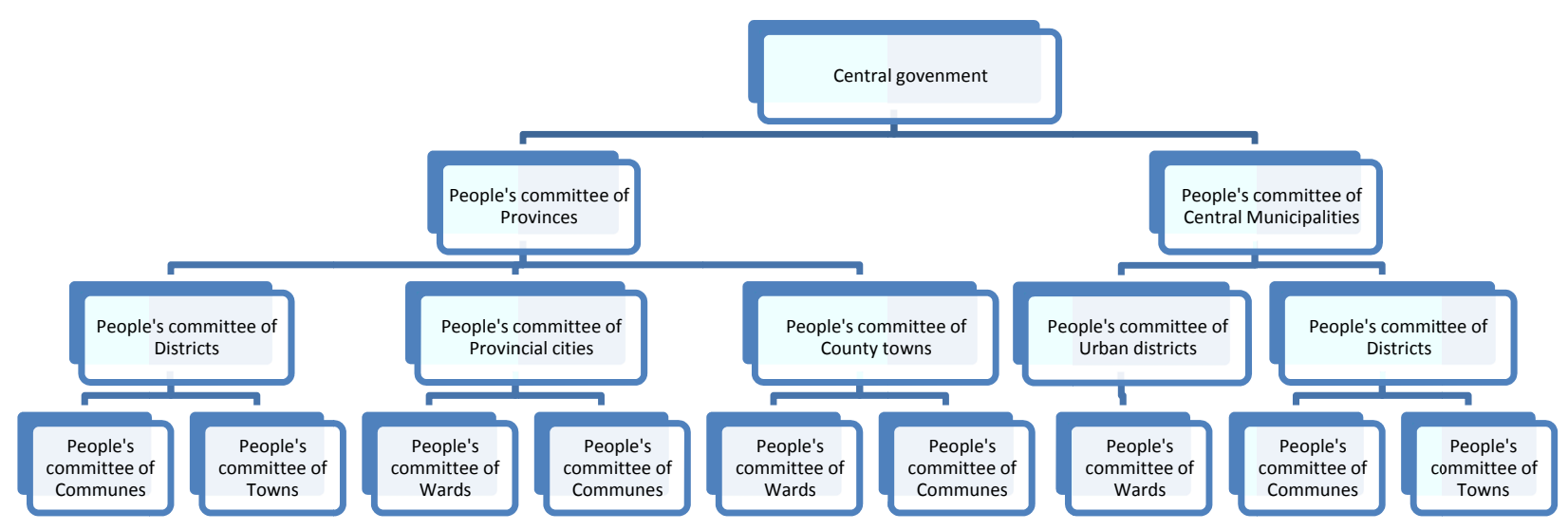

Figure 3. The executive body

Source: 2013 Constitution

The figures above illustrate the territorial division and structure of government. The Socialist Republic of Vietnam has sixty-three provinces and central municipalities, each province (or central municipality) has their own authority that manages all activities in their areas. Local power is monitored by the central government and must adhere to national laws. Central organizations manage local authorities by laws, regulations and through control. The government passes the annual activity plans of provinces (municipalities) and directs their budgets. Furthermore, to balance the development among provinces, the central government stipulates that wealthier provinces (municipalities) have to contribute a percentage of their local income to the central budget. In other words, the government subsidizes poorer provinces. According to this mechanism, every province manages its own plan to develop its territory. Evidently, there is little relationship with neighboring provinces. Ideally, inter-regional complications are supposed to be solved by the central government.

\subsection{Regional Administration}

The territorial divisions revealed have been helpful for Vietnamese management and development for a long time. On the other hand, the Socialist Republic of Vietnam has now engaged in an innovation process. It needs to build a plan for its regions with some provinces and cities that can shape urban economic centers to stimulate stronger socio-economic development. Officially, there are nine regions in the Socialist Republic of Vietnam, but the government is determined by key economic regions with three being the nucleus: Hanoi (the State capital), Ho Chi Minh City, and Da Nang. Hanoi region consists of Hanoi, Hai Phong and five provinces, Ho Chi Minh City region has eight members, and Da Nang has five (As shown Figure 4). There is no governmental management or organization for regions, just steering committees. These committees were founded to direct some fields such as transportation, construction, and economic development. These organizations have a duty to advise local governments to execute regional planning. Although there is the Chairman, who is the Deputy Prime Minister in Hanoi region, regional committees seem inoperative. Most regional committees function under the central government but their activities are rather modest, or inactive. The Chairperson of Committees is nominated and is usually incumbent to a region's Chairpersons of the People's Committee of Provinces. In addition, the central government also assigns the Ministry of Construction and the Ministry of Planning and Investment, as well, the provincial, or city governments are responsible for facilitating collaboration in regional planning. The division into regions is based on geographical positions, economic roles, and by the agreement of localities. On occasion, decisions are based on historical narrative or by the dominant ethnic group. In the Socialist Republic of Vietnam, except for the three key economic regions that could get results, the other regions function worse in comparison when it comes to development. The role of central government to its regions seems to demonstrate such an imbalance through its decision to authenticate or help regional planning. The implementation of regional control, and aid to other regions after decisions, is rather poor. Therefore, new benefits, or achievements, for the other regions in the Socialist Republic of Vietnam are difficult to realize. Many specialists comment that Vietnamese regions operate without combined interests. As well, the regional establishment is nominal and the exploitation of regional advantages are still distant. 


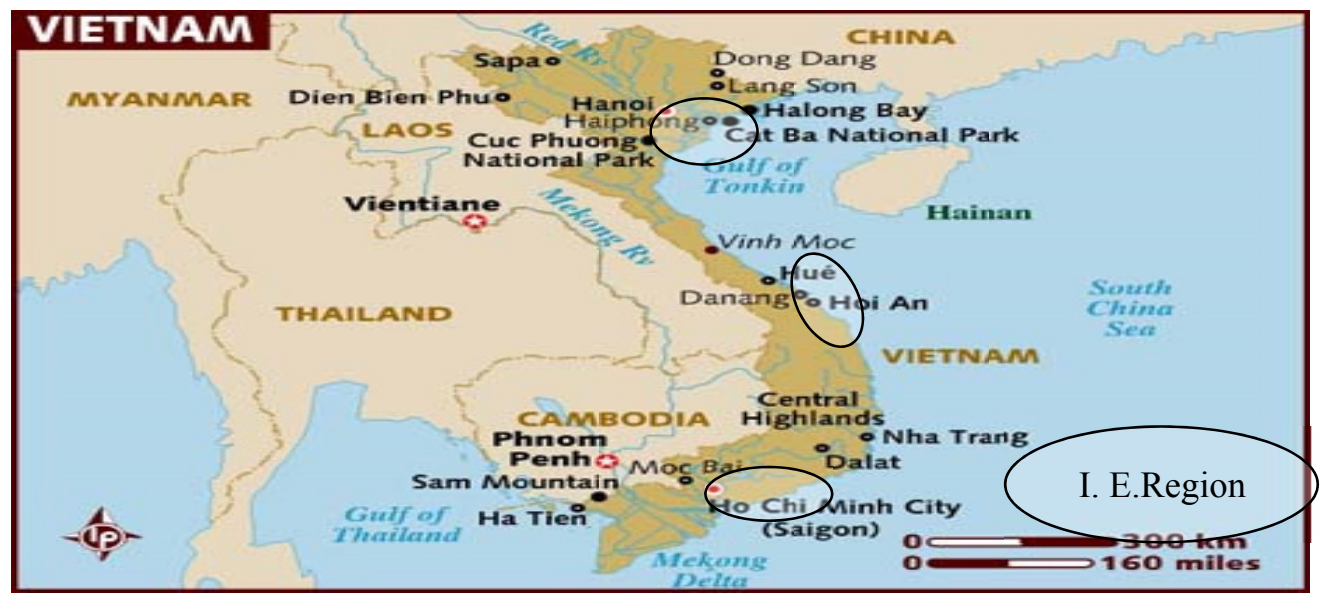

Figure 4. Important economic (I.E.) regions of the Socialist Republic of Vietnam

\subsection{The Results of Territorial Division and Regional Planning}

The Socialist Republic of Vietnam has sixty-three provinces and municipalities with decentralization. Decentralization has encouraged the creative vitality of local authorities, especially in economic planning and for the emerging market economy. The central government grasps the power to monitor regulations initiated by local governments and to balance development among provinces. Annual provincial plans, being socio-economic, have to be approved by the central government. Under Vietnamese law, central authority withdraws a percentage of income from wealthier provinces and subsidizes poorer ones with that income. This aims to create equal development throughout the Socialist Republic of Vietnam.

With a view to build strong economic regions, which become motive forces of the country, the government has established key economic regions as its strategy along with steering committees to conduct this campaign. This idea to build up strategic economic regions is sensible and received the support of planners. In reality, this mode of management has achieved some results. For instance, every province (municipality) tried to develop their yearly target towards improving their socio-economic structure. Such competition helped localities and the whole country achieve some results in economic and infrastructural development, especially in GDP growth (As shown Figure 5). This territorial division encouraged local governments to enlist the aid of central government, being the external investment that contributed to local development. Such emulation sped up national growth. However, there is still a gap among provinces.

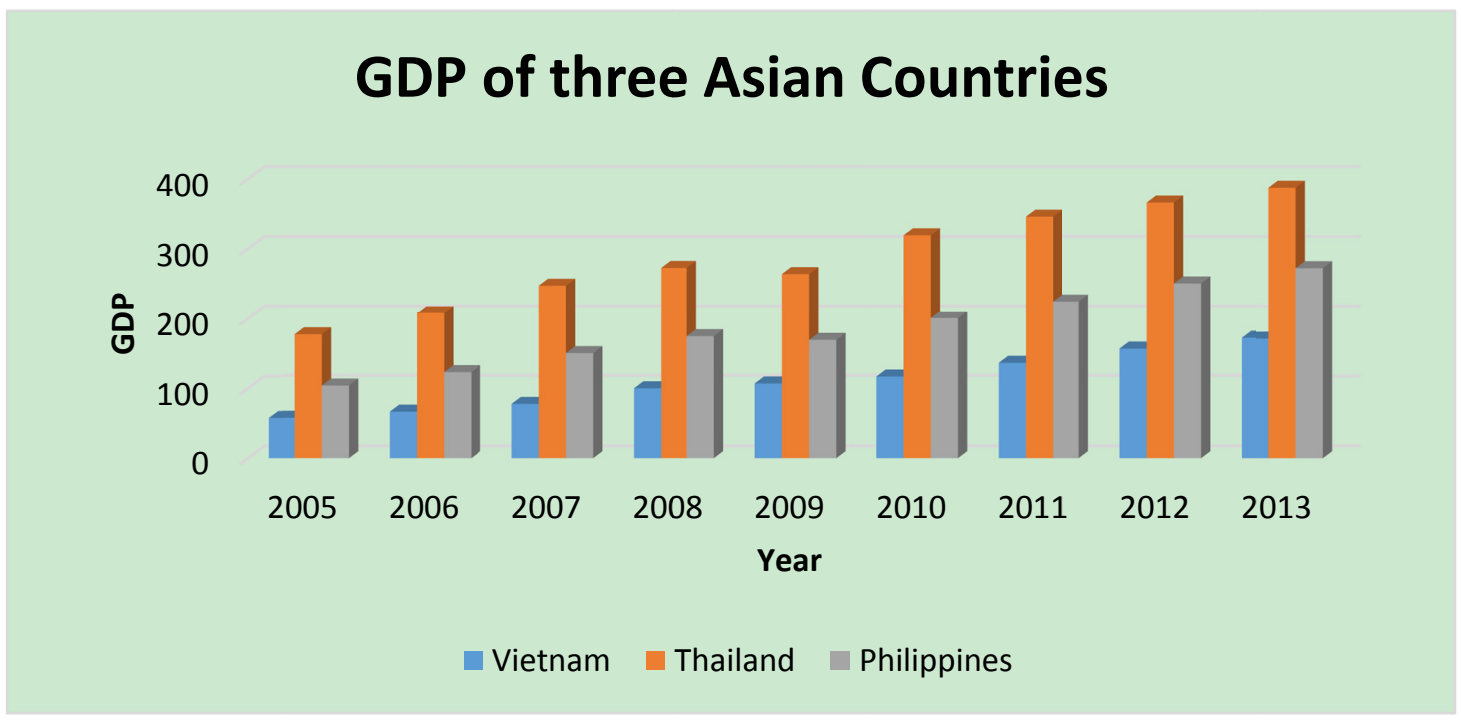

Figure 5. The GDP of the Socialist Republic of Vietnam and Neighboring Asian Countries (bill. \$US) Source: World Bank 
The grand application of planning for key economic regions has achieved significant progress, especially in infrastructure. In the last ten years, the Ministry of Transportation has completed many highways and national roads to connect cities and provinces, which are very important in order to develop urban areas and industrial zones. Furthermore, the Electric Power Company of Vietnam $(E V N)$ developed a rather decent power supply system and has met the demand of the socio-economic structure (As shown Figure 6). This is a fundamental basis for urban and industrial development. Beside that, Vietnamese telecommunication systems have seen phenomenal growth from 2000 to 2010. Ten years ago, the Socialist Republic of Vietnam ranked low among other Asian countries. Today, it is one of the most developed in regards to the internet and telecommunications on the continent. Ho Chi Minh City, Da Nang, and Hanoi are developing astonishingly and have become the country's main urban centers. These key centers have spread their dynamic activities to nearby localities. As a result, neighboring localities are also enjoying development. There are models such as Binh Duong and Ba Ria Vung Tau in Ho Chi Minh City region, Quang Nam of Da Nang region, and Hung Yen of Hanoi region. Numerous industrial parks have been built around these key centers, which have encouraged the economic growth of nearby provinces. Past policies triggered higher growth when the Socialist Republic of Vietnam established a market economy. The territorial division of the Socialist Republic of Vietnam, the organization of the government structure and the distribution of power achieved some active results, especially during the period of economic reform with the first phase of market economy.

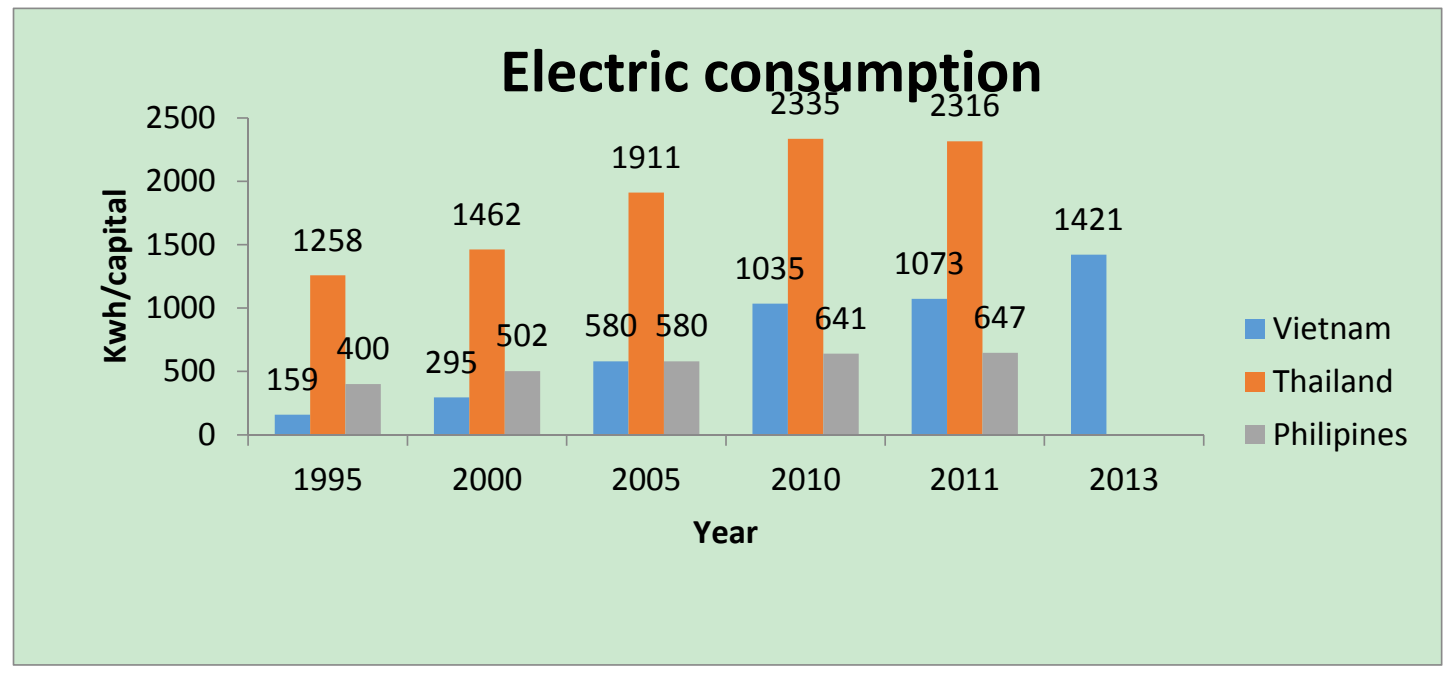

Figure 6. Electric consumption in the Socialist Republic of Vietnam and neighboring countries

Source: World Bank

\section{Problems and Reasons}

Despite positive results, this management system also confronts difficulties and faults that have been made, which hinders national and regional growth in the present Vietnamese market economy.

\subsection{The Gap in Development}

The territorial division and local organization of the Socialist Republic of Vietnam has evidently caused unequal development among provinces and cities. Local governments concentrate on their own targets through decisions by their People's Councils. Therefore, they cannot enlist their advantages to boost quick regional economic growth. This creates a big gap in development among provinces and cities (As shown Figure 7). Wealthier localities have more capital to improve infrastructure in comparison to their poorer counterparts. They are able to attract more investment and their income per capita is much stronger. The balance of central government is evident, despite difficulties in reducing the gap in development. This situation is not only a reality among Vietnamese provinces and cities, but also in the key economic regions. Essentially, with advantages in infrastructure and human resources, central cities of a region usually develop faster than their nearby provinces, which depend on the agricultural sector. Although provinces are trying to develop their own industrial and service sectors, the gap in Vietnamese socio-economic development is still rather extraordinary due to weaker infrastructural environments. As well, the low budgets of localities are an issue. This is a barrier which hinders the development of a whole region. Therefore, wise government policies are needed to resolve this crucial 
imbalance among provinces and cities.

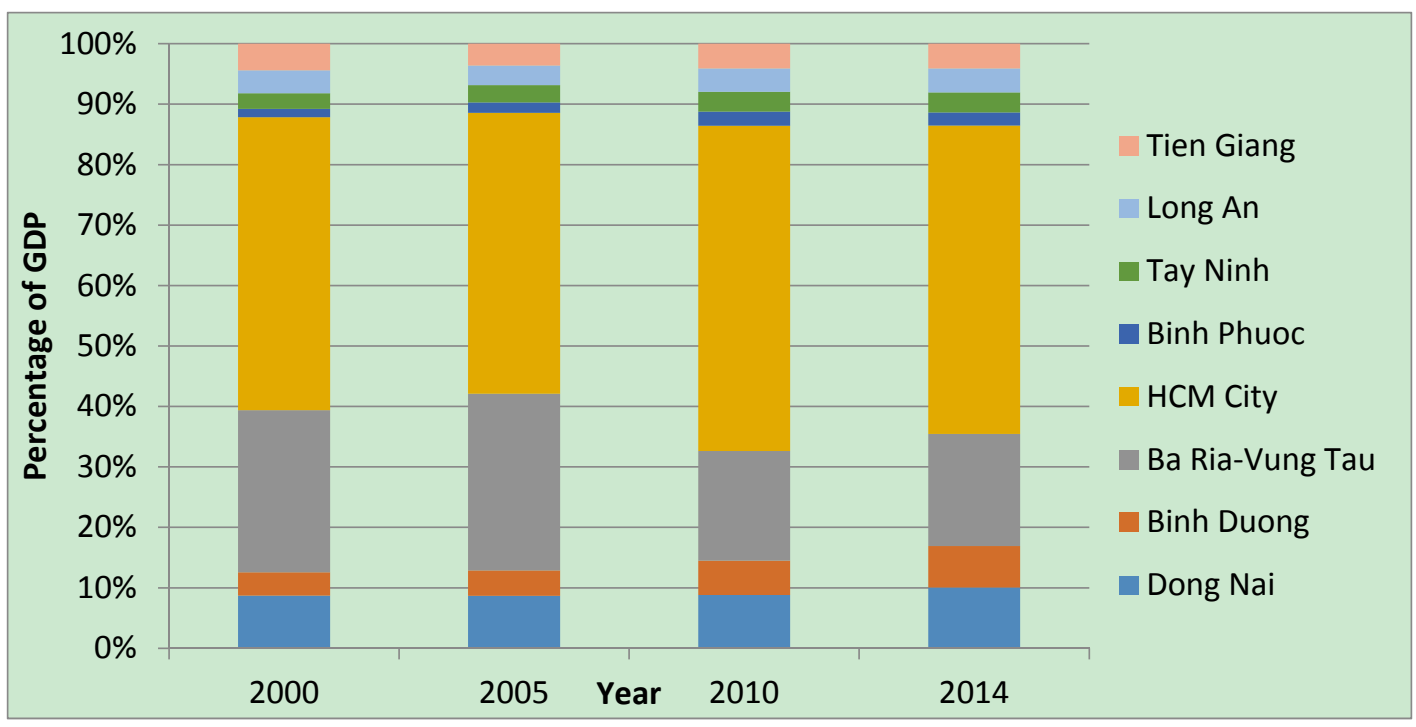

Figure 7. The Gap of GDP in Ho Chi Minh City Region

Source: General Statistics of Vietnam

\subsection{The Lack of an Effective Regional Management Body}

When the government planned its key economic regions, they intended to build strong economic centers with big cities as the nucleus. The central government assigns the Ministry of Planning and Investment and the Ministry of Construction to design regional planning. Steering committees were assigned to realize these plans. They consist of provincial (cities) leaders and they vote for an alternative Chairperson, who serves a one year term, to manage the committee. This management mechanism of regions is inoperative due to the fact that provincial leaders are equally ranked. It is difficult for a Chairman of a province to command other Chairmen. Furthermore, steering committees have no budget to decide inter-regional constructions in infrastructure, except for electric and road systems built through national plans. In fact, every province focuses on own target and neglects the concerns and plans of others. On occasion, there is unfair competition among regions in economic development and steering committees cannot arbitrate, especially in attracting investment and guaranteeing environmental protection. In addition, Vietnamese law is lacking in providing those who have responsibility, such as local governments, in managing regional issues. There is a common belief that only the central government has to perform this duty. Perhaps, this is the biggest obstacle that hinders the realization of regional development.

\subsection{Regional Economic Planning}

In regional planning, based on the advantages of provinces and cities, planners usually assign which economic sectors can adapt to localities. This can lead to one province being able to develop industry and services over the other. However, regional planning determines this for agricultural areas as well. In the view of regional planning, this arrangement seems reasonable because the advantages of exploitation will encourage effective economic development. However, there is no equalization of income in regions. For instance, the agricultural provinces always stand at a lower development level in comparison to their industrial counterparts. This is the reason that localities will not accept economic regional planning. They attempt to develop three economic sectors being industry, services, and agriculture, despite regional planning. In the key economic regions, each member (province or city) tries to develop urban areas, industrial zones, and other infrastructure. They neglect the plans of neighboring provinces. We see spontaneous construction which wastes capital, resources, and creates unfair competition among provinces in areas that encourage attractive investment. The central government recognizes this problem. Unfortunately, there is no intervention due to regulations and impositions. The balance of government is not strong enough to combat this issue.

\subsection{Planning for Urban and Industrial Infrastructure}

Problems in urban planning appear undoubtedly in economic zones. Evidently, planners are at fault for making inadequate calculations, or estimates, in regards to who will inhabit residential areas or new urban quarters. 
Many urban areas cannot develop and lot of residential quarter projects has been lacking customers for many years (As shown Figure 8). The root of the problem is mistakes made by managers who forecast wrongly about the tendencies of where inhabitants in a region will be concentrated. Managers have planned specific areas for urbanization; on the other hand, customers choose other areas to settle. The consequences of these inadequate projections are evident in the self-development of town houses along roads and suburban residential quarters; while these project areas of regional planning are rather deserted. This spontaneous development leads to complications of traffic jams and accidents. The problem of proper drainage is another issue created by these mistakes. As a result, the cost of urban renewal rises (As shown Figure 9).

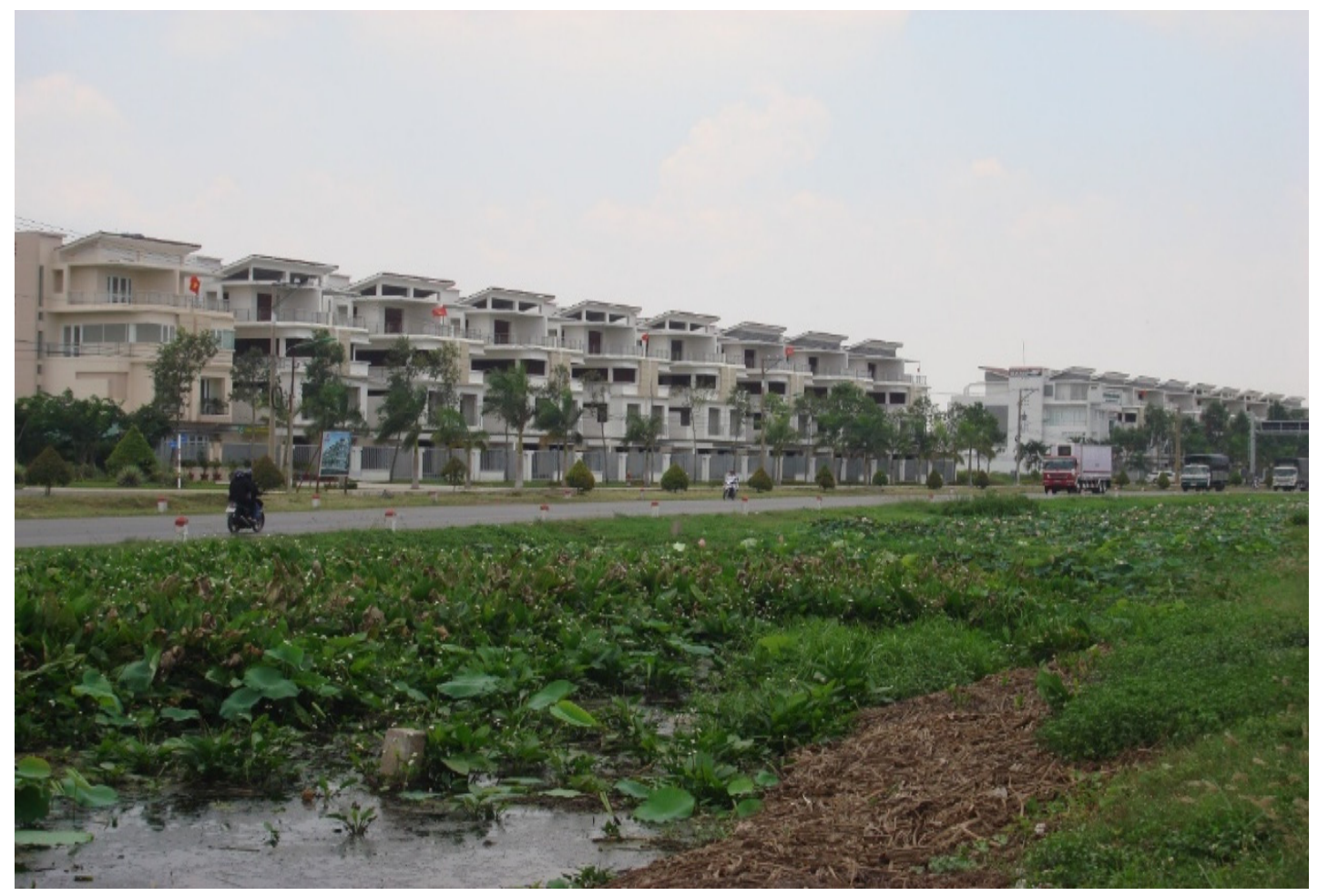

Figure 8. An unmarketable residential quarter

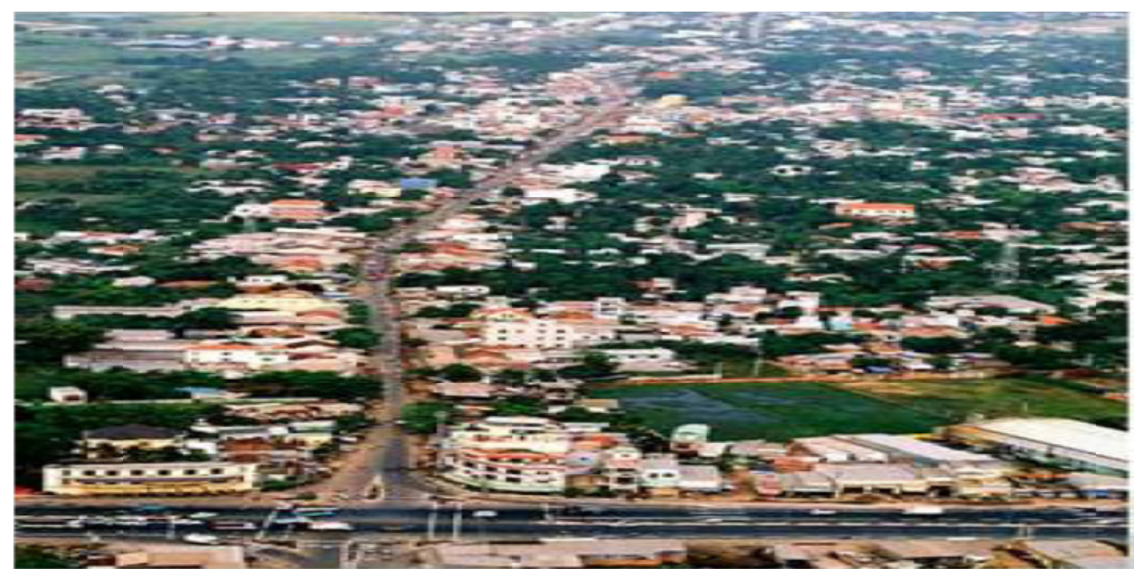

Figure 9. Spontaneous development

Evidently, there is a lack of collaboration among provincial governments in regards to the construction of infrastructure. There are exceptions for projects such as national highways, telecommunications, and electric systems, which belong to the ministries. Other infrastructural systems are built to solely serve only the localities of provinces.

The development of water supplies is a case in point. For example, Ho Chi Minh City has built its own water 
supply systems that are situated near provinces such as Long An and Dong Nai. However, Sectionalism makes each locality build its own systems despite being located nearby. Arguably, this has caused great waste in investment. This has also occurred in regards to the construction of waste treatment. We see a scattered disposition of waste solution that has increased the cost of treatment. As a consequence, regional inhabitants have to pay higher fees for garbage. Another fault is that despite there being plans for regional transportation systems and provincial roads that connect to Ho Chi Minh City, there seems to be a lack of combined interest, even among some provinces. However, this is also lacking for cities and vice versa. Therefore, regional transportation systems have developed slowly, especially in how roadways are connected. Recently, many provinces and cities have proposed seaport projects, but suffer from the lack of appraisal. Many debate whether these seaport initiatives would be beneficial or not. A lot of regional seaports have been constructed. However, they have been rather inefficient, as in the case of particular seaports being Hiep Phuoc, Thi Vai, and Cai Mep.

The construction of industrial parks is another mistake created by regional management, provinces, and cities in attempts to build more industrial zones. They aim to encourage investments for industrialization and to accumulate budgets. This leads to a surplus of industrial parks, which makes it difficult to lease land. As a result, these investments became unprofitable and cause a waste in land usage (As shown Figure 10).

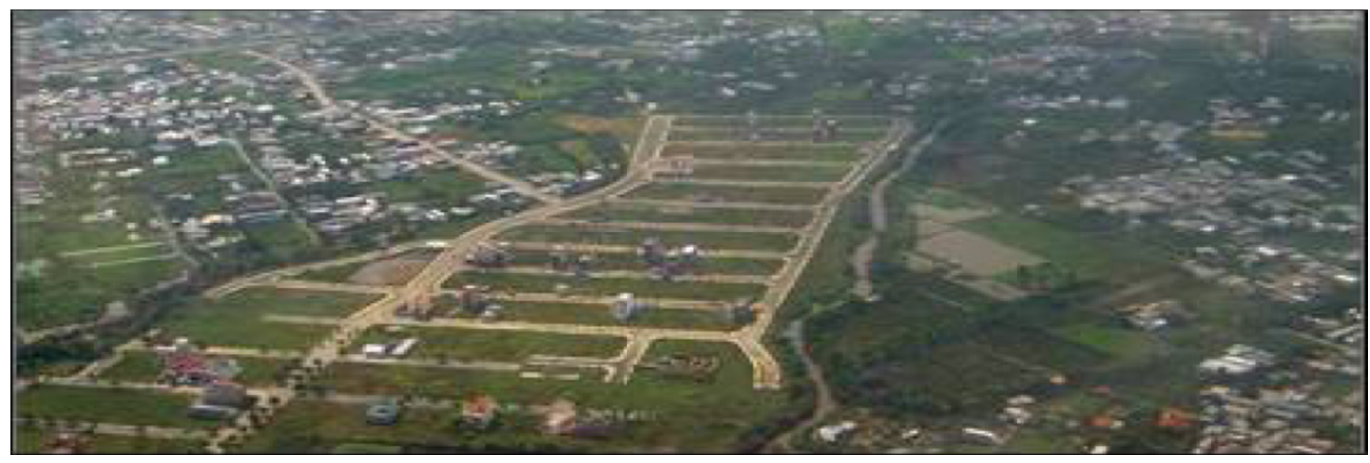

Figure 10. Land wasted

\subsection{Private Investment in Urban Areas and Industrial Zones}

In the Socialist Republic of Vietnam, especially in its key economic zones, private investors are also at fault in implementing planning due to self-interest. When the government lacks the budget and experience to develop urban areas and industrial zones, the mobilization of other resources to speed up economic growth proves to be a clever resolution. However, regional governments have made mistakes because they cannot control private investors. Normally, the private sector always considers its own income as the sole purpose of investment. As a result, urban or industrial area projects are damaged by private investors. If the authorities cannot control this, planning suffers. This has happened in the key economic regions, especially in Ho Chi Minh City region. The Southern Saigon urban area is an example where private investors have damaged regional planning. The failure of these private investors comes from financial resources they rely upon. Private investments in urban and industrial zones are based mainly on bank loans. When there were troubles of interest, many projects had to prolong or fail miserably. These problems engender stagnation in the implementation of regional planning.

\subsection{The Role of the Central Government}

Decentralization gives the central government a role in managing how regional planning is implemented. The central government monitors local activities that are related to regional planning, especially in how they are executed. In addition, the central government has an obligation to solve the divergence of local authorities and guide them in implementing regional planning. Essentially, the central government needs to make investments in inter-regional infrastructure such as water supplies, electricity, waste treatment, highways, and national roads. To promote the capacity of these common constructions and the development of a respective region, issues of Localism and unfair competition between cities and provinces must be solved. Unfortunately, the central government is rather frail in resolving regional issues, except for constructions in electricity, telecommunications, and highway expansion. Difficulties in regional infrastructure and plan implementation for such seem limited and local governments have to fend for themselves. Clearly, this leads to complications.

\subsection{The Difficulties of Land Clearance and Compensation}

Faults in the implementation of regional planning create issues in how land is utilized for planned projects of 
infrastructure for urban areas and industrial zones. Undoubtedly, more land is needed for this undertaking. According to Vietnamese law, land is state property and can serve as a special good. The government does grant land rights for citizens when it needs to utilize land for a specific purpose. The government will compensate a landowner by granting them limited ownership. In return, landowners have to give their land back to the government. In reality, this is very complicating and the implementation of regional planning suffers as a consequence. Reasons for this vary, such as compensation, resettlement policies, public support, and the purpose of projects. Evidently, almost all projects have confronted this difficulty. The utilization problem of land in the Socialist Republic of Vietnam causes inefficiencies for regional planning.

\subsection{The Competence of Management in Local Authorities}

Together with irrational regional authority and its structural organization, another fault lies with local governance and its fragile ability in implementing planning. This fallacy of planning in a market economy seems rather common. Local governments use to motivate planners to draw from their own ideas, even if such ideas had no relation to any regulation or scientific analysis. This direction is all too familiar with economic centralization that occurred in the past, where government performs all the work in implementing planning. As a result, these plans lack a real market economy. As a consequence, this creates an excess of urban areas, industrial zones, and infrastructural projects that also prove inefficient. Arguably, the fault lies with local leaders and advisors.

\section{International Experiences}

Difficulty arises when trying to apply a methodology of planning from one country to another. Every country has its own political establishment, form of economic development, and level of education among its masses. However, some international experiences can be referred to and serve as lessons for local or central governments that seek to correct its faults in implementing regional planning.

\subsection{Japanese Regional Management}

Japan is divided into cities and provinces. Under a province, there are provincial cities, districts, towns and villages. Recently, Japan has almost urbanized all its countryside and there are only a few villages left. Japan organizes the government level of cities, provinces, towns, districts, and villages. In Japan, regions have no official administrative units, but its government is divided into eight regions being Hokkaido, Tohoku, Kanto, Chubu, Kansai, Chugoku, Shikoku, and Kyushu. Regional governments are absent but the central government stipulates the collaboration of local governments that aim to develop the economy, keep security, and implement regional planning. In Japanese regions, there has been tremendous collaboration between local authorities in performing planning with the central government. In Kansai region, the water supply companies of cities and provinces, which are mostly state owned, have strong associations. Many Japanese cities face the issue of fresh water depletion. In order to solve this issue, the Japanese government and the water companies have exploited resources from its regions and distributed enough water for all its cities and inhabitants.

In Japan, land utilized for agriculture and construction is very scarce. The government compensates private land usage for the leveling of mountains and the filling of bays. This provides enough land for construction. Planning for new urban areas, industrial parks, airports, highways, railways, and other infrastructural projects is also provided. Planners also make adequate calculations for inhabitants that will settle in new areas. For instance, an inhabitants' means, how they commute to work, and other demands they have in life are carefully calculated. Japanese authorities carefully pass the details of planning, organize the construction of basic infrastructure for electricity, water supplies, communication systems and then the private sector plays a role by investing in project components with government supervision. This methodology is successful for regional planning in Kansai region. For instance, Kobe City has developed new industrialized urban areas, new centers and an airport in Osaka Bay (As shown Figure 11).

What is evident about Japanese Regional Management is that the organization of regional government is nonexistent. However, the central government provides aid for planning and finances regional works. In addition, local governments seek collaboration with each other, especially with inter-cities, or provinces, in regards to issues related to waste treatment, water supplies, and transportation. Japan has a narrow landscape so planning is done sensibly, and the direction of regional governments maintains an adequate environment that is suitable for human development. Another Japanese experience we can learn from is the mobilization of resources. Local governments effectively enlist aid provided by the central government in order to build basic infrastructure. Simultaneously, exploitation occurs, with private sector help, through implementation and this maintains regional planning. The spirit of Japanese people is also represented in the implementation of regional planning. Evidently, the issue of Localism is absent. The Japanese government and its citizens collaborate together in regional planning. Arguably, this reveals how Japanese regions develop quickly despite having restricted 
resources and geographical complications. Evidently, Japan's eight regions have shared spoils in both socio-economic development and urbanization. Specifically, the collaboration of local governments has in fact helped this Land of the Rising Sun create an exceptional model for others to study.

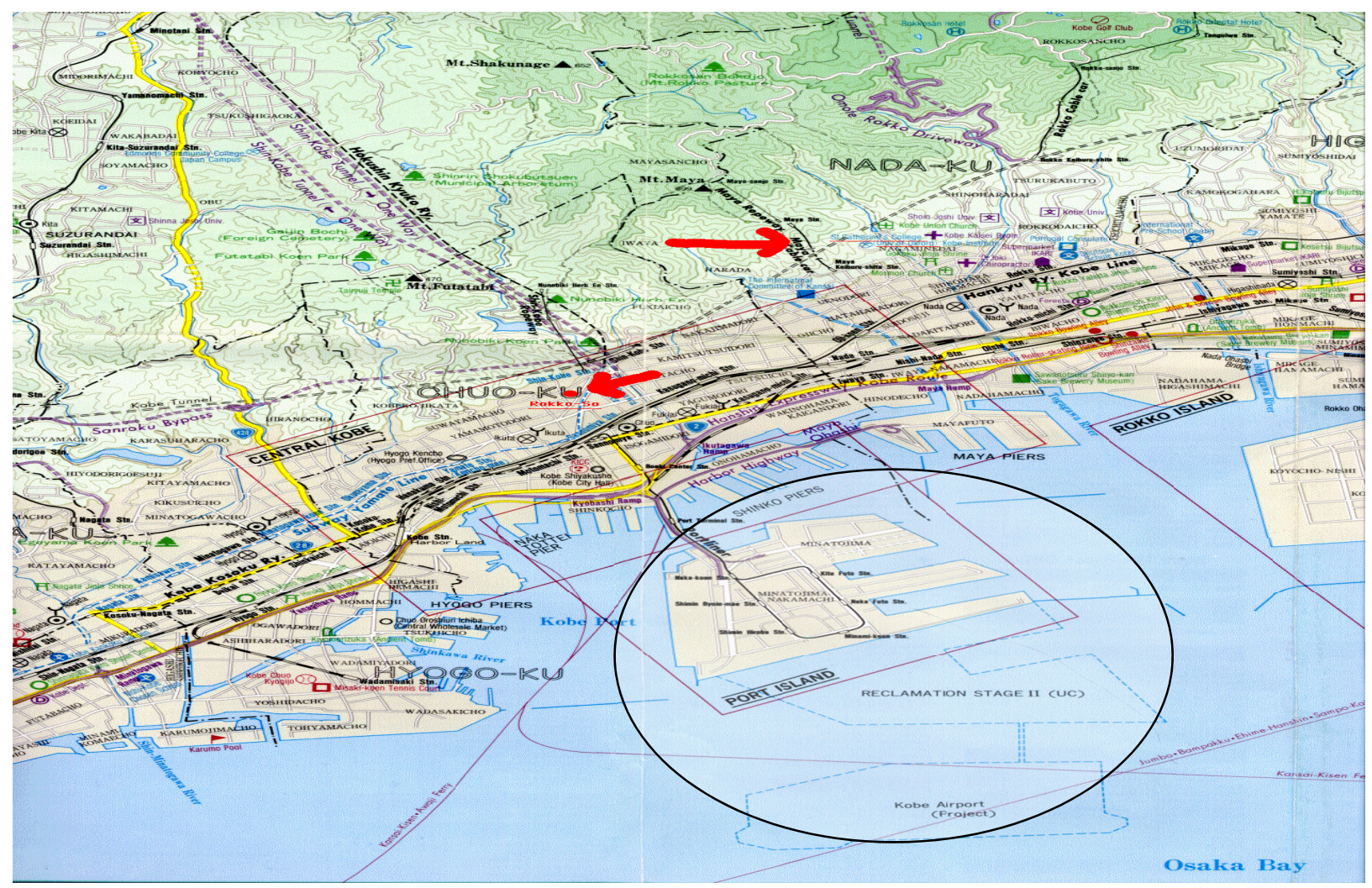

Figure 11. Enlarged plan of Kobe City, Kansai Region

Source: www.citiesgallery.com

\subsection{The Lesson of L'Ile de France}

During the late 1950s, Paris was a monocentric agglomeration of 8.4 million inhabitants. There was a concentration of workers at the heart of city, a shortage of housing, and a lack of transportation for inhabitants to commute to work. In addition, a lack of railways and freeways was apparent and hurt Parisian development. As a result, the French government sought out a plan to change Paris from a monocentric agglomeration into polycentric urban area. There were many phases of planning from 1965 to 2015. Eventually, the French government organized assistant bodies for this undertaking. The central government also adjusted regional planning when socio-economic changes occurred, especially when an oil crisis happened. It also embraced a new trend of development to make Paris a major center in the European Union (EU). As well, this leads to the creation of green city. To implement regional planning in L'Ile de France, the government established strong organizations which performed the main works. For example, Institut d'aménagement et d'urbanisme de la Région Parisienne (the Institute of development and planning in the Paris region) carried out studies related to regional planning. As well, Zones d'aménagement différé (Deferred Development Areas) supplied land funds. Land purchasing became the duty of Agence foncière et technique de la Région Parisienne (the Land and technical agency in the Paris region), and Établissements publics d'aménagement (the Public development establishment) was responsible for urban development. The duty of these bodies was performed with local authorities so they could implement successful regional planning. The plan has been carried out in more than fifty years and transformed Paris into an EU center (Laurent, 2014). What we learn from the experience of L'Ile de France is that the right participation of central government, collaboration among local authorities, and the timely adjustment of regional planning is critical in achieving results in development. Furthermore, reasonable investment in infrastructure for newly planned areas is crucial (As shown Figure 12). 


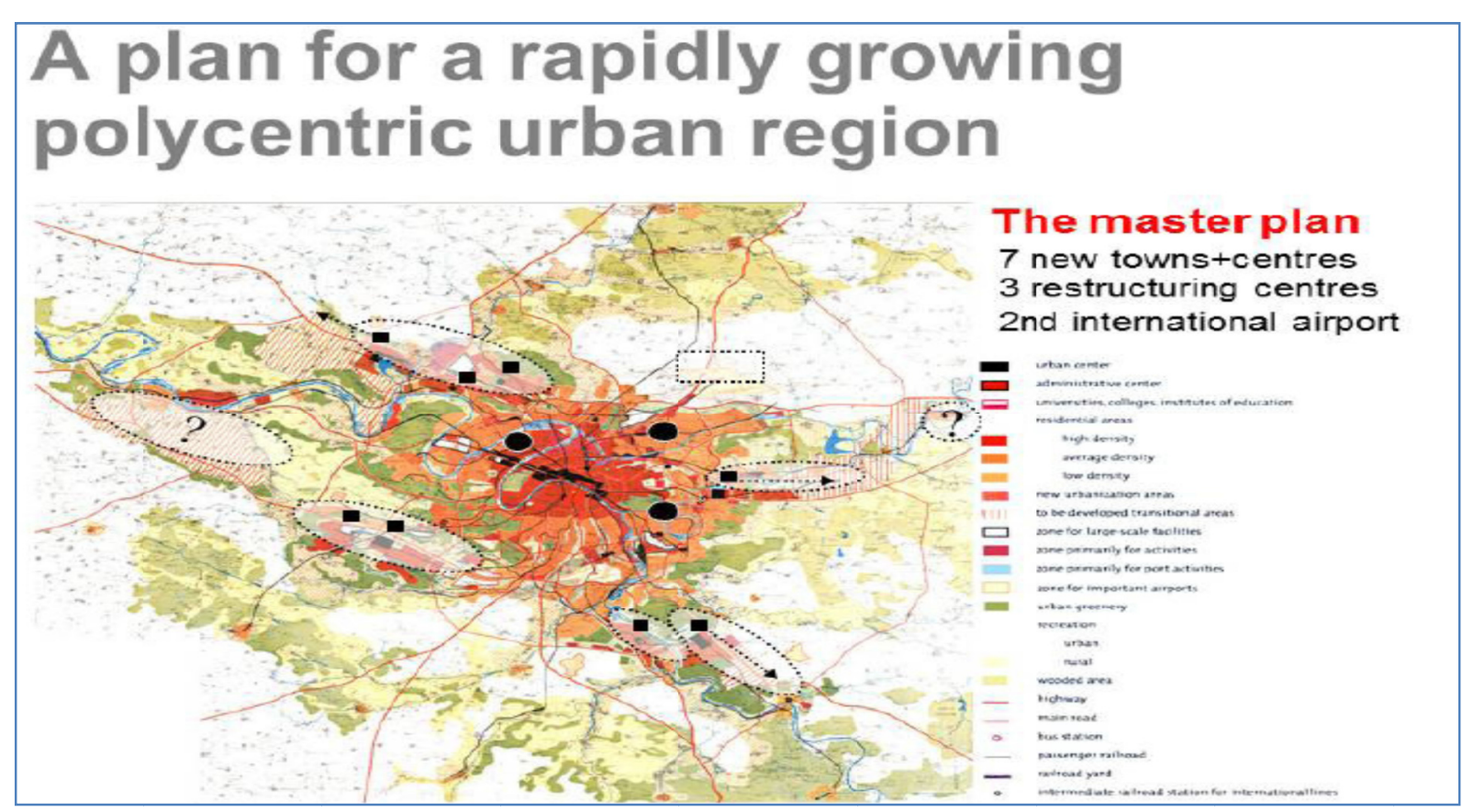

Figure 12. L'Ile de France Region and its Polycentric Plan

Source: IAU- IdF

\subsection{Governance and Decentralized Concentration Orientation of Berlin-Brandenburg Region (Federal Republic of Germany)}

Berlin has a similar situation to other big cities worldwide, as a growing Metropolis in the middle of Brandenburg. Germans have intended to enlarge their capital so that Berlin's area serves as one of Europe's most important centers. To make this a reality, the German government concentrates on some important aspects that can stimulate the development of a region. According to German specialists, governance and urbanized regional structures are the most important for development.

In Berlin-Brandenburg Region, planning tasks, comprising the metropolis and the neighboring areas, are concentrated in one authority. In 1996, the German government established Die Gemeinsame Landesplanungsabteilung Berlin-Brandenburg (The Joint Spatial Planning Department of Berlin-Brandenburg), which has been responsible for state planning and regional development in that particular region. This is an important mechanism to create and control state development plans. Also, they organized an Urban Forum, where central and local authorities share information and negotiate regional policies. The German government also established a Generalversammlung (General Assembly) and Arbeitsgruppen (Workgroups) who serve as main actors and decide on key plans. There is combination of approaches from the state and local level, including strengthening the power of local collaboration in vertical negotiations.

The federal acts and policies approve decentralized concentration in spatial planning throughout the Federal Republic of Germany. This is a guiding principle embodied at the federal level by der Raumordnungsgesetz (the Federal Spatial Planning Act) and die Raumordnungspolitik (the Spatial Planning Policy) guidelines. The implementation of decentralized settlement structures for the regional and national territory, with many urban regions and centers, aims to prevent the overstraining of strong spatial disparities in growing regions. For the region of Berlin-Brandenburg, orientation of decentralized concentration is applied so that Berlin is the metropolis. The cities of Brandenburg are arranged as centers with specific functions for its populace (Stefan, 2014) (As shown Figure 13). 


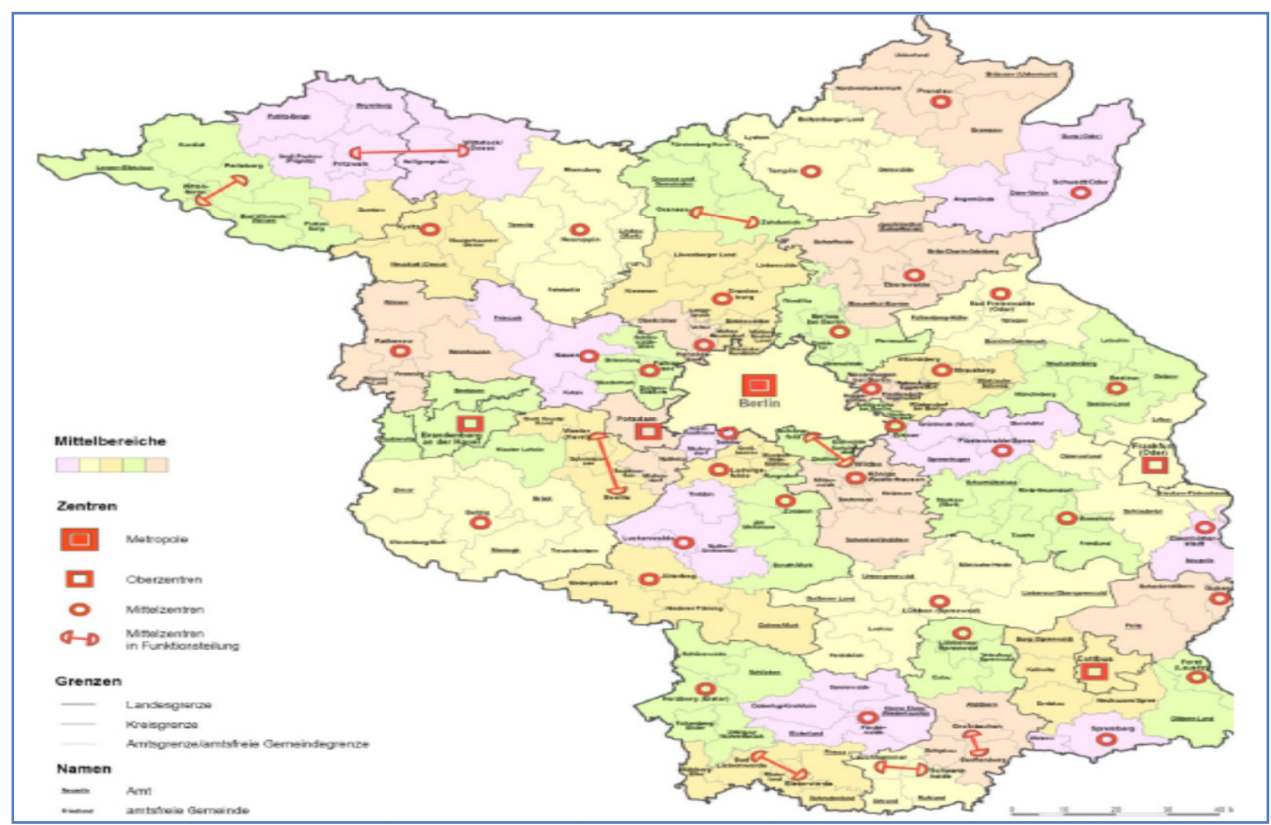

Figure 13. Berlin-Brandenburg Region

Source: Stefan Elsing

\subsection{The Linkage of Urban Areas in Some Countries}

In the late of nineteenth century, the United States had a tendency to link urban regions that aimed to restructure and improve governmental organizations. Based on Regionalism, they organized regional governments and this proved rather successful with the unification of four counties and twenty-four areas which founded the City of Greater New York. Other American cities have achieved success when they applied this model such as Jacksonville, Indianapolis, and Nashville (Ye, 2009). However, nearly $85 \%$ of applications in thirty-four cities and counties at that time failed. The reason is that according to American constitutional and administrative laws, the power of local government is rather strong, so they have enough dominion to protest regional unification. They argued that the new model can cause tax burdens for citizens. Since the 1990s, a new brand of Regionalism has appeared and changed regional governance. This linkage tendency is based on the pragmatic coordination model with many approaches such as linked functions and complex networks. In other words, this model encourages voluntary collaboration of local governments that resolve the problems in regional management and creates an adequate environment for development (Leland et Thurmaier, 2000).

In the People's Republic of China, the government has considered regional linkage for nearly thirty years. They issued many policies of regional collaboration to solve the socio-economic problems of its regions. In the strongly developed East Sea Coast region, local governments have an active role in linkage that aims to create regional collaboration, and generate power for international competition. In the less developed urban areas of Mainland China, the central government has the main role in regional collaboration, especially in investments for infrastructure. The intervention of central government has affected the development of poorer urban areas, which struggle to catch up with the more developed regions (Ye, 2009). With these models, the People's Republic of China has been successful in socio-economic development and encouraged urbanization on a national scale in the last twenty years. Evidently, Chinese urban areas have well exploited the advantages of regional development with a vertiginous velocity.

The Republic of Indonesia is a developing country and there are urban regions that have been founded due to the spontaneous links of cities and rural areas. The government also considers encouraging regional development. For instance, Yogyakarta is one typical model of region linkage. This region includes Yogyakarta City, which has a financial and educational function. Other districts, such as Sleman and Bantul, undertake residential and other service functions. In 2001, a regional governing body was established with the approval of local governments. The duty of this organization is implementation, control, and evaluation of regional planning for infrastructure. Yogyakarta region has a multi-tiered governmental structure. At beginning, it had six tasks being solid waste 
treatment, potable water, waste water, drainage, roadway construction, and circulation. In 2006, the government supplemented spatial development planning, one of the most important tasks of regional management (Hudalah, 2013).

\section{Proposals}

With experiences of the Socialist Republic of Vietnam and lessons from other countries, the author would like to propose some resolutions as a means to solve the problems in the implementation of Vietnamese regional planning.

\subsection{Regional Management System}

One of the most serious issues with the key economic regions is that they hinder the development and regional advantages for exploitation due to the lack of an effective management body. As mentioned before, with the current government structure and Localism, it is rather difficult to perform successful regional planning. Without changes in the executive body, to have an effective regional administration, the central government would have to decide on a committee for regional governance. The leaders of this committee would be designated by the central government with the agreement of local authorities. However, it cannot nominate the Chairman of Provinces (cities) as the alternative Committee Chairman. This selection of regional leadership has been a failure in the past. The committee must be strong enough to implement inter-regional duties. In addition, this committee will receive funds from the government budget for their obligations. The committee tasks should relate to common regional works such as spatial development planning and infrastructure. These works are determined as the ones that stipulate the development of all regions. The power of the committee can equalize investments in regional infrastructure. Therefore, less developed areas can move forward and achieve greater development. Evidently, the problem for this organization of management is the quality of committee members and the support of local governments.

\subsection{The Role of Government in Planning}

In implementing regional planning, central and local governments have a very important role. Major and spatial planning are the core of regional development and they are built by competent organizations. As well, it is better that these strategies receive the support of local governments and their inhabitants. In first phase of implementation, the government should participate directly in planning, land clearance compensation, and in building infrastructure. Then, private investors should be invited to take part in regional planning under the control of the government in such a way that the plan has to be observed. The central government uses regional committees and ministerial organizations as tools to perform the spatial planning and to integrate urban and rural areas within regions. This regional governance takes on inter-area construction in infrastructural projects of energy, water-supplies, waste treatment, telecommunications, and transportation systems. Moreover, regional governance has a duty to integrate local governments in development. Although the Socialist Republic of Vietnam applies a policy of decentralization, provincial (city) governments need to extrude Localism in order for all localities to develop strongly. Therefore, regional collaboration in economic and infrastructural construction has to be regulated by the central government (Savitch et Vogel, 2010).

\subsection{Market Economy and Regional Planning}

In the implementation of Vietnamese regional planning, there are some leadership that still cling to the ideas of economic centralization. Therefore, they have not calculated carefully in regards to who will buy property in regional projects and other facilities that attract inhabitants to locate. Many urban residential areas have been deserted while many inhabitants concentrate on other spontaneous quarters because the demand and whether inhabitants can afford to locate on planned areas is miscalculated. For instance, some residential projects were far from customers' working places, there was lack of transportation, a lack in infrastructure and too expensive to purchase. Many industrial zones cannot attract secondary investors because of the unfavorable situation. Clearly, these projects have caused waste in resources and disorder in planning. To resolve this problem, the government needs to issue regulations that limit inefficient projects by careful project appraisal and solve delayed projects. Therefore, the government needs to release residency restriction to help the development of urban areas and encourage investors to consider many credible market sectors that can exploit in collaboration with the government. In other words, market residential areas for low and medium incomes. In addition, small and medium enterprises should be the target market for industrial parks.

\subsection{Difficulties in Resolution, Management and Professional Problems}

Many mistakes in Vietnamese regional planning can be circumvented if the government hires earnest planners and pursues the consultation of inhabitants and specialists. As well, local authorities may select powerful 
investors to implement planning. Local governments need competent consultants to help them in making decisions related to the planning of regional development. It needs vibrant, reasonable compensation policies to solve the immense obstacles such as land clearance. Moreover, strict regulation should be issued to prevent the spontaneous construction and improper land utilization to assure regional planning functions adequately.

\section{Conclusion}

In an environment of globalization, the development of regions is tangible. The Socialist Republic of Vietnam has the advantages of geophysics and strong economic development. Furthermore, the key economic regions are situated near important maritime and air traffic routes. Therefore, if the government has suitable policies, these regions of the Socialist Republic of Vietnam may well become the urban or economic centers of Asia. This development needs the wise management of authorities, which remove the obstacles of regional development. The most important demand is a strong regional management body which can solve issues effectively. We cannot negate the development of Ho Chi Minh City, Da Nang, or Hanoi, but in the view of Regionalism, growth is rather disappointing. If authority handles and solves early regional problems, perhaps Vietnamese regions might develop quicker and the Socialist Republic of Vietnam could possibly overtake other Asian countries. The experience of the People's Republic of China, with good management, in few decades, allowed many poor regions to become highly developed areas of Asia such as Shenzhen, Hsiamen, and Zhuhai. These proposals are the ones for government to consider. A strong change of perspective in leadership needed, so regions can grow quicker and become a source of motivation for the whole country. There are many viewpoints on regional development, from each district as an agro-industrial fortress in economic planning to the Localism of provinces in recent days. Barriers that hinder the performance of regional planning still exist in some regions. The experiences of regional planning from other countries cannot be applied entirely in the Socialist Republic of Vietnam. However, many of them are valuable lessons to learn from, such as having competent regional governance, free competition in a market economy, wise decision making in spatial regional planning, flexibility in long-term planning application, the transition of the economy with regional planning, and the exclusion of Localism. Finally, management in regional planning and its implementation impacts strongly in regards to the growth of a country. A wise change can help the Socialist Republic of Vietnam move forward and become a model itself to be studied.

\section{References}

Elsing, S. (2014). Sustainable Mobility in Metropolitan Areas and Asian Megacities. International Conference Proceeding- Planning Concepts for the revised Ho Chi Minh City region, plan 2030 and vision 2050. HCM City, December, 2014.

General Statistics. (2014). Statistical Year book. Statistic publisher, Hanoi, 2014.

Hudalah, D. et al. (2013). Regional governance in decentralizing Indonesia: Learning from the success of urban-rural cooperation in metropolitan Yogykarta. Cleavage, Connection and conflict in Rural, Urban and Contemporary Asia, 3, 65-87. Retrieved from http://www.springer.com/us/book/9789400754812

Laurent Perrin- IAU-d'Ile de France. (2014, December). From an agglomeration to a metropolitan region: Mastering the development of Paris-L'Ile-de-France 1965-2013. International Conference ProceedingPlanning Concepts for the revised Ho Chi Minh City region, plan 2030 and vision 2050. HCM City.

Leland, S. M., \& Thurmaier, K. (2000). Metropolitan Consolidation Success: Returning to the Roots of local government reform. Public Administration Quarterly, 24(2), 202-213. Retrieved from https://www.questia.com/read/1P3-70073689/metropolitan-consolidation-success-returning-to-the

National Assembly of Vietnam. (2013). Constitution of Vietnam 2013. Hanoi, November, 28-2013.

Savitch, H. V., \& Vogel, R. K. (2000). Introduction "Paths to New Regionalism". State and Local Government Review, 32(3), 158-168. http://dx.doi.org/10.1177/0160323X0003200301

Ye, L. (2009). Regional Government and Governance in China and the United States. Public Administration Review, 69(s1), S116-S121. http://dx.doi.org/10.1111/j.1540-6210.2009.02098.x

\section{Copyrights}

Copyright for this article is retained by the author(s), with first publication rights granted to the journal.

This is an open-access article distributed under the terms and conditions of the Creative Commons Attribution license (http://creativecommons.org/licenses/by/3.0/). 